Mehmet ARSLAN1

Cengiz ERDURMUŞ2

Mehmet ÖTEN2

Bilal AYDINOĞLU1

Sadık ÇAKMAKÇI1

${ }^{1}$ Akdeniz Üniversitesi, Ziraat Fakültesi, Tarla Bitkileri Bölümü, 07058, Antalya / Türkiye

2Batı Akdeniz Tarımsal Araştırma Enstitüsü

Müdürlüğü, 07100, Antalya / Türkiye

sorumlu yazar: mehmetarslan@akdeniz.edu.tr

Anahtar Sözcükler:

Mısır silajı, Leucaena leucocephala L., silaj fermantasyonu, besleme değeri

\section{Mısır (Zea mays L.) ile Leucaena leucocephala L. Bitkisinin Karıştırılmasıyla Hazırlanan Silajların Besin Değerinin Belirlenmesi}

\author{
Determination of Nutritive Value of Maize (Zea mays L.) \\ Silages Ensiled with Leucaena leucocephala L.
}

Alınış (Received): 21.04.2016 Kabul tarihi (Accepted): 10.11.2016

\section{ÖZET}

u çalışmada mısırın (Zea mays L.) Leucaena leucocephala L. ile farklı oranlarda D karışımı ile elde edilen silajların ham besin maddesi içeriklerini ve kalite özelliklerini belirlemek amaçlanmıştır. Bu amaçla mısır bitkisine \%0 (kontrol), $\% 20, \% 40$ ve $\% 60$ oranında L. leucocephala karıştırılarak, her silaj grubundan 6 tekerrür olacak şekilde toplam 24 adet silaj yapılmıştır. Fermantasyon sonunda yapılan analizlerde, L. leucocephala'nın karıştırıldığı silajlarda ham protein (HP), ham kül (HK), ham selüloz (HS), nötr deterjan lif (NDF), suda çözünebilir karbonhidrat (SÇK), laktik asit bakterisi (LAB) ve laktik asit içeriklerinde önemli artışlar belirlenmiştir. Saf mısır silajına göre L. leucocephala ilave edilen silajlarda daha düşük oranda kuru madde (KM), ham yağ (HY), asit deterjan lif (ADF) pH, asetik asit ve bütirik asit seviyeleri belirlenmiştir. Sonuç olarak, mısırın L. leucocephala ile birlikte karışım olarak silolanması başta HP içeriğinin yüksekliği olmak üzere, daha kaliteli silajlar elde edilebileceği ve L. leucocephala'nın silaj bitkisi olarak değerlendirilebileceği görülmüştür.
Key Words:

Maize silage, Leucaena leucocephala L., silage fermentation, nutritive value

\begin{abstract}
This study was conducted to determine the crude nutrient contents and quality characteristics of silages prepared from the mixture of maize (Zea mays L.) and Leucaena leucocephala L. within the proportions of \%0 (control), $20 \%, 40 \%, 60 \%$ respectively. Totally 24 silages were made with 6 repetitions in each. In L.leucocephala mixed silages, crude protein, crude ash, crude cellulose, notr detergan fiber and lactic acid showed significant increase, however; dry matter, crude oil, acid detergan fiber, pH, acetic acid and butyric acid decraesed significantly. In conclusion, it is observed that when the maize crop is silaged with $L$. leucocephala, more qualified silages can be retained with high crude protein content and that $L$. leucocephala can be appraised as silage forages.
\end{abstract}

\section{Giriş}

Hayvan beslemede ihtiyaç duyulan ve kısa sürede temin edilebilen kaliteli, bol ve ucuz alternatif kaba yemler, silolamaya uygun yem bitkilerinden elde edilebilir. Silaj, besin maddelerindeki değer kaybını en aza indiren, su içeriği yüksek kaba yem özelliği ile gelişmiş ülkelerde yoğun olarak kullanılmaktadır (Geren 2001; Weinberg ve Ashbell 2003). Bu açıdan bakıldığında, mısır diğer birçok yem bitkisine göre, verim ve kalitesiyle silaj yapımında potansiyeli yüksek bir bitki olup, Dünya'nın birçok bölgesinde yaygın olarak kullanılmaktadır (Meeske ve ark. 1993).

Mısır bitkisi, bünyesinde bulundurduğu ve silaj yapımında arzu edilen düzeyde laktik asit fermantasyonunun gerçekleşmesi açısından önem taşıyan kuru madde, suda çözünebilir karbonhidrat içeriği ve buffer kapasitesi ile ideal bir silaj materyali konumundadır (Silva ve ark. 2015). Ham protein içeriğinin yetersizliği ise mısırın temel dezavantajı olarak kabul edilmektedir. Silolama esnasında üre 
katkısı yapılması, mısırın protein içeriği yüksek bitkisel materyallerle karışım halinde silolanması bu anlamda başvurulan temel uygulamalar arasındadır (Mc Donald ve ark. 1991; Filya 2004).

Mısır ile karışım halinde silolanabilen bir bitki de, tropik bölgelerde yayılmış, küçük ağaç tipinde, yaz periyodunda hızlı gelişen, çok yıllık bir baklagil olan Leucaena leucocephala L. bitkisidir. L. leucocephala değişik bölgelerde deniz seviyesinden başlayarak 1800 $\mathrm{m}$ yüksekliklere kadar olan yerlerde yetişebilmektedir. Çok lezzetli bir otu olan L. leucocephala, yetişme bölgelerine göre değişmekle birlikte başta ham protein (\% 10.00-30.05) ve karbonhidrat (\% 40-45) olmak üzere birçok mineral yönünden zengin olup \% 28.00-32.00 arasında ham selüloz içermektedir (Skerman ve ark. 1988; Meena ve ark. 2013). L. leucocephala tropik bölgelerde hayvansal ürünleri arttırabilmek için besleyici bir yem ağacı olarak yaygın bir biçimde kullanılmakla birlikte, bünyesinde bulunan ve mimosine olarak bilinen amino asitten dolayı otlanma sıklığına bağlı olarak ruminantlarda beslenme rahatsızıklarına sebep olabilmektedir (Garcia ve ark. 1996).

Bu çalışmada, özellikle süt sığırcılığının en ucuz kaba yem kaynağı olan ve hayvanlar tarafından sevilerek tüketilen mısır silajının protein içeriği bakımından zenginleştirilmesine yönelik olarak L. leucocephala'nın farklı oranlarda karıştırılmasıyla elde edilen silajların temel besin maddesi içerikleri ile fermantasyon özelliklerini belirlemek amaçlanmıştır.

\section{MATERYAL ve YÖNTEM}

\section{Bitkisel Materyal Temini ve Silaj Yapımı}

Bu çalışmada silaj yapımında kullanılan bitkisel materyallerden mısır (Zea mays L.) Batı Akdeniz Tarımsal Araştırma Enstitüsü'nde yetiştirilmekte olan Şafak çeşidinin hamur olum döneminde (\% 30-35 KM) (Filya, 2004) hasat edilmesiyle; Leucaena leucocephala L. ise Akdeniz Üniversitesi Ziraat Fakültesi Uygulama Tarlalarında yetişmekte olan bitkilerden taze dal ve yaprakların hasat edilmesi ile elde edilmiştir. Elde edilen bu bitkisel materyaller yaklaşık olarak $2 \mathrm{~cm}$ boyunda parçalanıp küçültülerek kuru madde üzerinden ağırlık esasına göre planlanan oranlarda (Çizelge 1) karıştırılarak her bir silaj grubundan 6 tekerrür olacak şekilde, 1.5 litre kapasiteye sahip sadece gaz çıkışına izin veren özel cam kavanozlara (Weck, Wher-Oftlingen, Germany) sıkıştırılarak doldurulmuştur.

Çizelge 1. Hazırlanan Silajlar
Table 1. Prepared Silages
\begin{tabular}{ll} 
Silaj Adı & Silaj içerikleri \\
\hline M80+L20 & Mısır $(\% 80)+$ L. leucocephala $(\% 20)$ \\
M60+L40 & Mısır $(\% 60)+$ L. leucocephala $(\% 40)$ \\
M40+L60 & Mısır $(\% 40)+$ L. leucocephala $(\% 60)$ \\
M100 & Mısır $(\% 100)$ \\
\hline
\end{tabular}

\section{Kimyasal ve Mikrobiyolojik Analizler}

Silolar cam kavanozlarda 60 gün boyunca laboratuar koşullarında $\left(24 \pm 4{ }^{\circ} \mathrm{C}\right)$ tutulduktan sonra açılarak kimyasal analizleri yapılmış, fermantasyon özellikleri ve mikrobiyolojik özellikler incelenmiştir. Silajlar etüvde $65{ }^{\circ} \mathrm{C}^{\prime}$ de 48 saat süreyle tutulduktan sonra $1 \mathrm{~mm}$ elek çapında değirmende öğütüldükten sonra gerekli analizler yapılmıştır. Silajların KM, HK, HP içeriklerinin saptanmasında Kjeldahl metodu kullanılmıştır (Akyıldız 1984). Silajlarda hücre duvarının yapısında bulunan NDF ve ADF ise Van Soest ve ark. (1991), tarafından bildirilen yöntemlere göre belirlenmiştir. Diğer yandan, laktik, asetik ve bütirik asit değerleri de Lepper'in kısaltılmış yöntemine (Akyıldız 1984) göre bulunmuştur. SÇK içerikleri ise fenol sülfürik asit yöntemine göre belirlenmiştir. $L A B$, maya ve küf sayımları da Seale ve ark. (1990)'nin bildirdiği yönteme göre yapılmıştır. Ekim ortamı olarak LAB için MRS agar, maya ve küfler için ise Malt Ekstrat agar kullanılmıştır. Silaj örneklerindeki LAB, maya ve küf sayımları $30^{\circ} \mathrm{C}^{\prime}$ de 3 günlük inkübasyon süresi sonunda gerçekleştirilmiştir. Elde edilen değerler logaritma koliform ünite/g olarak verilmiştir.

\section{İstatistiksel Analiz}

Araştırmada elde edilen verilerin istatistiksel olarak değerlendirilmesinde, Tesadüf Parselleri Deneme Desenine göre varyans analizi, ortalamalara ait farklılıkların belirlenmesinde ise Duncan (1955) çoklu karşılaştırma testi uygulanmıştır. Bu amaçla SPSS paket programı kullanıımıştır.

\section{ARAŞTIRMA BULGULARI}

Misırın \% 20, 40 ve 60 oranlarında L. leucocephala otu ile karıştırılarak hazırlanmış silajların kimyasal analiz sonuçları Çizelge 2'de verilmiştir. Çizelge 2 incelendiğinde mısır ile L. leucocephala bitkisinin karıştırılmasının silajların kimyasal içeriklerini önemli düzeyde etkilediği saptanmıştır $(p<0.01)$. KM içeriğ bakımından en yüksek değerin (\%44.42) saf mısır silajından elde edildiği, en düşük değerin ise (\%32.58) L. leucocephalánın \%60 oranında katıldığı silajdan elde edildiği görülmektedir. Diğer yandan, 
L. leucocephala bitkisinin silaja katılma oranı arttıkça kuru madde oranının düştüğü tespit edilmiştir. Silajların HP içerikleri ise \% 5.95 (M100) ile \% 16.26 (M40+L60) arasında değişim göstermiştir. Mısıra ilave edilen L. leucocephala bitkisinin oranı arttıkça silajların
HP içerikleri de doğru orantılı şekilde artmıştır. Bununla birlikte, L. leucocephala bitkisinin silaja katılması HS ve NDF içeriği de bir miktar yükselişe sebep olurken ADF oranında bir miktar azalmaya sebep olmuştur.

Çizelge 2. Mısır silajlarının kimyasal analiz sonuçları, \%

Table 2. Results of chemical analysis in maize silages, \%

\begin{tabular}{lllllllllll}
\hline Silajlar & KM & HP & HY & HK & HS & NDF & ADF & SÇK & Ca & P \\
\hline M80+L20 & $40.85 b^{*}$ & $9.28 \mathrm{c}$ & $2.64 \mathrm{~b}$ & $2.70 \mathrm{~d}$ & $23.03 \mathrm{a}$ & $37.83 \mathrm{a}$ & $20.62 \mathrm{a}$ & $1.64 \mathrm{~b}$ & $0.85 \mathrm{a}$ & $0.17 \mathrm{a}$ \\
M60+L40 & $34.67 \mathrm{c}$ & $14.05 \mathrm{~b}$ & $3.27 \mathrm{a}$ & $3.41 \mathrm{a}$ & $22.91 \mathrm{a}$ & $37.88 \mathrm{a}$ & $18.07 \mathrm{~b}$ & $1.54 \mathrm{~b}$ & $1.08 \mathrm{a}$ & $0.15 \mathrm{a}$ \\
M40+L60 & $32.58 \mathrm{~d}$ & $16.26 \mathrm{a}$ & $3.20 \mathrm{a}$ & $3.29 \mathrm{~b}$ & $21.83 \mathrm{bc}$ & $35.75 \mathrm{a}$ & $18.64 \mathrm{~b}$ & $1.35 \mathrm{c}$ & $0.58 \mathrm{~b}$ & $0.17 \mathrm{a}$ \\
M100 & $44.42 \mathrm{a}$ & $5.95 \mathrm{~d}$ & $3.43 \mathrm{a}$ & $2.79 \mathrm{c}$ & $2167 \mathrm{c}$ & $28.16 \mathrm{~b}$ & $21.58 \mathrm{a}$ & $2.16 \mathrm{a}$ & $0.53 \mathrm{~b}$ & $0.17 \mathrm{a}$ \\
\hline Önem Düzeyi & $* *$ & $* *$ & $* *$ & $* *$ & $*$ & $* *$ & $* *$ & $* *$ & $* *$ & od \\
\hline
\end{tabular}

x: Sütun içerisinde aynı harfleri alan ortalamalar arasında istatistiki olarak önemli bir farklılık yoktur $(\mathrm{p}<0.05)$.

öd: Önemli değildir. *: Farklılıklar 0.05 seviyesinde önemlidir. **: Farklılıklar 0.01 seviyesinde önemlidir. KM: kuru madde; HP: ham protein; HY: ham yağ; HK: ham kül; HS: ham selüloz; NDF: nötr deterjan lif; ADF: asit deterjan lif; SÇK: suda çözünebilir karbonhidrat; Ca: kalsiyum; P: fosfor.

Silajların fermantasyon özelliklerine ait verilerin sunulduğu Çizelge 3 incelendiğinde ise bazı uçucu yağ asidi ve $\mathrm{pH}$ değerlerinin önemli düzeyde farklı olduğu görülmektedir $(p<0.01)$. En yüksek $\mathrm{pH}$ değeri (4.42) saf mısır silajından elde edilirken diğer silajlarda daha düşük değerler belirlenmiştir. Silo ortamındaki LAB sayıları incelendiğinde (Çizelge 4) en yüksek miktarın M40+L60 silajından elde edildiği ve yine bu silajlarda laktik asit oluşumunun daha yüksek olduğu tespit edilmiştir. Elde edilen sonuçlar silo ortamında arzu edilen bakteri grubu olan LAB sayısının baklagillerin karışıma girme oranlarıyla doğru orantılı olarak yükseldiğini göstermektedir.

Çizelge 3. Mısır silajlarının fermantasyon özellikleri

Table 3. Fermentation chracteristics of maize silages

\begin{tabular}{lllll}
\hline Silajlar & $\mathrm{PH}$ & Laktik asit (\%) & Asetik asit (\%) & Bütirik asit (\%) \\
\hline M80+L20 & $4.23 \mathrm{bc}^{\mathrm{x}}$ & $2.42 \mathrm{c}$ & $1.28 \mathrm{ba}$ & 0 \\
M60+L40 & $4.32 \mathrm{ba}$ & $4.32 \mathrm{a}$ & $1.25 \mathrm{ba}$ & 0 \\
M40+L60 & $4.10 \mathrm{c}$ & $3.45 \mathrm{~b}$ & $1.07 \mathrm{~b}$ & 0 \\
M100 & $4.42 \mathrm{a}$ & $3.29 \mathrm{~b}$ & $1.46 \mathrm{a}$ & 0.02 \\
\hline Önem Düzeyi & $*$ & $* *$ & $*$ & öd \\
\hline
\end{tabular}

x: Sütun içerisinde aynı harfleri alan ortalamalar arasında istatistiki olarak önemli bir farklılık yoktur $(p<0.05)$.

öd: Önemli değildir. *: Farklılıklar 0.05 seviyesinde önemlidir. **: Farklııklar 0.01 seviyesinde önemlidir.

Çizelge 4. Mısır silajlarının mikrobiyolojik özellikleri, $\log _{10} \mathrm{cfu} / \mathrm{g}$

Table 4. Microbiological chracteristics of maize silages, $\log _{10} c f u / g$

\begin{tabular}{llll}
\hline Silajlar & LAB & Maya & Küf \\
\hline M80+L20 & $2.00 \mathrm{c}^{\mathrm{x}}$ & $0.69 \mathrm{c}$ & $0.51 \mathrm{c}$ \\
$\mathrm{M} 60+\mathrm{L} 40$ & $3.83 \mathrm{~b}$ & $1.44 \mathrm{~b}$ & $0.80 \mathrm{~b}$ \\
$\mathrm{M} 40+\mathrm{L} 60$ & $4.62 \mathrm{a}$ & $2.01 \mathrm{a}$ & $1.11 \mathrm{a}$ \\
$\mathrm{M} 100$ & $2.38 \mathrm{c}$ & $0.54 \mathrm{c}$ & $0.18 \mathrm{~d}$ \\
\hline Önem Düzeyi & $* *$ & $* *$ & $* *$ \\
\hline
\end{tabular}

x: Sütun içerisinde aynı harfleri alan ortalamalar arasında istatistiki olarak önemli bir farklılık yoktur $(p<0.05)$.

**: Farklılıklar 0.01 seviyesinde önemlidir.

LAB: laktik asit bakterisi.

\section{TARTIŞMA ve SONUÇ}

\section{Silajların Kimyasal Bileşimleri}

Mısırın L. leucocephala ile \% 20, 40, 60 oranlarında karıştırılarak elde edilen mısır silajlarının kimyasal içeriklerine ait değerler Çizelge 2'de verilmiştir. Bu özelliklerden KM değerleri incelendiğinde, $L$. leucocephala bitkisinin silajdaki oranı arttıkça KM içeriğinin düştüğü görülmektedir. Bu durum, $L$. leucocephala'nın taze materyalindeki düşük KM oranından (Garcia ve ark. 1996) kaynaklanmaktadır. 
Aynı çizelgede verilmiş olan HP sonuçları detaylı bir şekilde incelendiğinde, L. leucocephala bitkisinin mısır silajına katılma oranları ile doğru orantılı olarak silajların HP içeriğinin de arttığı ve \% 16.26'ya kadar yükseldiği görülmektedir. Bu sonuçlar bir baklagil yem bitkisi olan L. leucocephald'nın yüksek protein içeriklerinden dolayı (Skerman ve ark. 1988; Garcia ve ark. 1996; Meena ve ark. 2013) beklenen sonuçlar olup, Titterton ve Maasdorp (1997), Koç ve ark. (1999), Carruthers ve ark. (2000), Dawo ve ark. (2007) ve Özdüven ve ark. (2009)'nın mısırı farklı baklagillerle siloladıkları çalışmalarla uyum içerisindedir. Diğer yandan, SÇK değerleri incelendiğinde, saf mısır silajının \% 2.16 ile en yüksek değere sahip olduğu görülmektedir. L. leucocephald'nın dahil olduğu silajlarda ise daha düşük SÇK değerleri elde edilmiş ve L. leucocephald'nın karıştırılma oranı arttıkça SÇK değeri düşmüştür. Filya (2004), homolaktik fermantasyon gelişiminin sağlanması bakımından önem taşıyan SÇK miktarının, mısır bitkisinde hamur olum döneminde $\%$ 2'nin üzerinde olduğunu bildirmektedir. $\mathrm{Bu}$ bakımdan L. leucocephald'nın bulunduğu silajlar SÇK bakımından yetersiz olup saf mısır silajı yeterli durumdadır.

Diğer yandan, HS ve NDF içerikleri de $L$. leucocephala'nın artmasına paralel olarak doğru orantılı biçimde önemli oranda artmış, ADF içeriği ise bir miktar azalmıştır $(p<0.01)$. Burada mısırın karbonhidrat içeriğinin bir baklagil olan L. leucocephala bitkisine göre daha fazla olması sebebiyle ortamdaki laktik asit bakterilerinin faaliyetini hızlandırması ve sonuç olarak da hücre duvarı bileşenlerinin parçalanmasında daha etkili olduğu tahmin edilmektedir. Bu durumu Filya (2001) ve Bolsen ve ark. (1996) da çalışmalarında tespit etmiştir. Silajların NDF ve ADF içeriklerindeki düşüşün, karbonhidrat kaynaklarının silaj ortamındaki laktik asit bakterileri ile birlikte bazı anaerobik bakterilerin sayılarının artması, ham selüloz, NDF ve ADF parçalanabilirliğinin hızlanmasından kaynaklandığını bildirmişlerdir. Bu özellikler açısından elde edilen değerler benzer konularda çalışma yapmış olan Aoki ve ark. (2013) ile Queiroz ve ark. (2013)'nın sonuçları ile uyumlu iken; Özdüven ve ark. (2009) ile Filya ve Sucu (2010)'nun sonuçlarından düşük kalmıştır.

Silajların HY ve HK içeriklerine bakıldığında (Çizelge 2) mısıra ilave edilen L. leucocephala'nın HY açısından bir miktar düşüşe sebep olduğu, HK açısından ise önemli oranda artışa sebep olduğu görülmektedir. Elde edilen değerler mısır silajı konusunda araştırma yapmış olan bazı araştırıcıların (Nursoy ve ark. 2003; Arslan ve Çakmakçı 2011; Queiroz ve ark. 2013) bildirdiği sınırlar içerisinde bulunmaktadır.

\section{Silajların Fermantasyon Özellikleri}

Silajların fermantasyon özelliklerine ait analiz sonuçları Çizelge 3'de verilmiştir. Mısır ile karışıma giren L. leucocephala bütün oranlarda silajların pH'sını önemli oranda düşürmüş ve farklılıklar istatistiki açıdan önemli bulunmuştur $(p<0.01)$. Çalışmaya ait $\mathrm{pH}$ değerleri incelendiğinde en düşük değerin (4.10) M40+L60 karışımından, en yüksek değerin ise (4.42) saf mısır silajından elde edildiği görülmektedir. Bu durumun SÇK içeriği düşük ve tamponlama kapasitesi yüksek olan baklagillerin mısırla iyi bir karışım oluşturarak kaliteli bir fermantasyonun gerçekleştiğinin göstergesi olarak ifade edilebilir. Elde edilen $\mathrm{pH}$ değerleri Koç ve ark. (1999), Carruthers ve ark. (2000), Filya (2004), Özdüven ve ark. (2009), Filya ve Sucu (2010)'nun bildirdiği sonuçlarla benzerlik göstermektedir. Silaj içerisinde gerçekleşen fermantasyon, silajların besleme değerini, açıldıktan sonraki dayanımını ve hayvanlar tarafından sevilerek tüketilmesini etkilemektedir. Fermantasyon sürecince ortamdaki $\mathrm{pH}$, amonyak ve organik asitlerin miktarı silaj fermantasyonu ve kalitesi değerlendirilirken kullanılan önemli kriterlerdendir (Canbolat ve ark. 2010, Filya 2001).

Silajların laktik asit değerleri incelendiği zaman, \%2.42 (M80+L20) ile \%4.32 (M60+L40) arasında değişen değerler elde edilmiştir (Çizelge 3). Bu durum baklagillerin karbonhidrat içeriği yüksek olan mısır gibi buğdaygillerle karışım halinde başarıyla silolanabileceğinin göstermektedir (Açıkgöz 2001; Filya 2001). Çünkü baklagil ilavesiyle ortam yeterince asidik hale gelmiş ve fermantasyon güvenilir şekilde gerçekleşmiştir. Nitekim, yüksek bir laktik asit içeriği sağlıkı bir fermantasyonun en önemli güvencesidir (Johnson ve Harrison 2001). Silajlarda bozulmanın bir göstergesi olan asetik asit içeriği ise \% 1.46 ile \% 1.07 arasında değişmekle birlikte, bütirik asit bazı silajlarda az miktarlarda da olsa tespit edilmiştir (Çizelge 3). Silajlarda tespit edilen uçucu yağ asitleri içerikleri incelendiğinde, sonuçların Titterton ve Maasdorp (1997), Geren ve Kavut (2009) ve Demirel ve ark. (2010)'nın bildirdiği sonuçlarla benzerlik gösterdiği anlaşılmaktadır.

\section{Silajların Mikrobiyolojik Özellikleri}

Silajlık mısırın farklı oranlarda L. leucocephala ile karıştırılarak silolanması, $L A B$ üretimini önemli düzeyde $(p<0.01)$ arttırmıştır. En yüksek $L A B$ değeri (4.62 $\log _{10} \mathrm{cfu} / \mathrm{g}$ ) M40+L60 silajindan elde edilirken, en düşük değer ise $\left(2.00 \log _{10} \mathrm{cfu} / \mathrm{g}\right) \mathrm{M} 80+\mathrm{L} 20$ silajından 
elde edilmiştir. LAB değerlerinde dikkat çeken başka bir nokta ise $L$. leucocephala'nın silaja katılma oranları arttıkça LAB sayıları yükselmektedir. Garcia ve ark. (1996) ve Meena ve ark. (2013)'nın da bildirdiği gibi $L$. leucocephala yüksek oranda protein içeren bir baklagil olmasının yanında \% 40 oranında da karbonhidrat içermektedir. Bu karbonhidrat içeriği laktik asit bakterilerinin ortamda çoğalmasında etkili olduğunun bir göstergesidir. Zaten, LAB bir silaj içerisinde dominant forma olması gereken bakteri grubudur (Weinberg ve Ashbell, 2003). Aslında LAB için daha fazla besin imkanı sağlanmış ve silo içerisindeki $L A B$ üretimi arttırılmıştır. Diğer yandan maya ve küf değerleri de kontrol olarak kullanılan saf mısır silajına göre yakın değerler vermiştir. Silajların mikrobiyolojik özellikleri kapsamında elde edilen bütün bu değerler, Titterton ve Maasdorp (1997), Koç ve ark. (1999), Geren ve Kavut (2009) ve Özdüven ve ark. (2009)'nın bildirdiği değerlerle paralellik göstermektedir.

Sonuç olarak; bu çalışmada silaj yapımında en fazla kullanılan bitki olan mısırın, tek başına silolanması sıkıntılı olan L. leucocephala ile karıştırılarak silolanmasının silaj kalitesinde iyileşmeler sağladığı

\section{KAYNAKLAR}

Açıkgöz E (2001) Yembitkileri. Uludağ Üniversitesi Basımevi, Yayın No: 7-025-0210. (Yenilenmiş 3. Baskı) 584 s. Bursa.

Akyıldız R (1984) Yemler Bilgisi Laboratuvar Kılavuzu. Ank Üniv Zir Fak Yayınları, No:358, Uygulama Kilavuzu: 122, s:174-185.

Aoki Y, Oshita T, Namekawa H, Nemoto E, Aoki M (2013) Effect of cutting height on the chemical composition, nutritional value and yield, fermentative quality and aerobic stability of corn silage and relationship with plant maturity at harvest. Grassland Science 59: 211-220.

Arslan M, Çakmakçı S (2011) Mısır (Zea mays) ve sorgumun (Sorghum bicolor) farklı bitkilerle birlikte yapılan silajlarının karşılaştırılmaları. Akdeniz Üniversitesi Ziraat Fakültesi Dergisi 24(1): 47-53.

Bolsen KK, Ashbell G, Weinberg ZG (1996) Silage fermentation and additives. AJAS Reviews. 9: 5, 483-489.

Canbolat Ö, Kalkan H, Filya İ (2013) Yonca Silajlarında Katkı Maddesi Olarak Gladiçya Meyvelerinin (Gleditsia Triacanthos) Kullanılma Olanakları. Kafkas Universitesi Veterinerlik Fakültesi Dergisi 19(2): 291-297.

Carruthers K, Prithiviraj B, Cloutier QFeD, Martin RC, Smith LD (2000) Intercropping of corn with soybean, lupin and forages: silage yield and quality. Journal of Agronomy and Crop Science 185: $177-185$

Dawo MI, Wilkinson JM, Sanders FET, Pilbeam DJ (2007) The yield and quality of fresh and ensiled plant material from intercropped maize (Zea mays) and beans (Phaseolus vulgaris). Journal of Science and Food Agriculture 87:1391-1399.

Demirel R, Saruhan V, Baran MS, Andiç N, Demirel DŞ (2010) Farklı Oranlarda Ak Üçgül (Trifolium repens) ve Arpa (Hordeum vulgare L.) Karışımlarının Silolanma Özelliklerinin Belirlenmesi. Yüzüncüyıl Tarım Bilimleri Dergisi 20 (1): 26-31. ortaya çıkmıştır. Araştırmada elde edilen bulgular, tek başına silolandığı zaman da iyi fermente olan ve hayvanlar tarafından sevilerek tüketilen ve dünya genelinde silaj amaçlı olarak en fazla üretimi yapılan bitki olan mısırın, yetiştiriciliği zor olmayan ve birçok amaç için zaten yetiştiriliyor olan L. leucocephala ile karıştırılarak birlikte silolanabileceğini göstermektedir. Karışım yapılırken L. leucocephalánın \%20 oranında silaja katılması silaj kalitesinde önemli artışlar sağlarken, $\% 60$ oranında ilave etmek daha büyük katkılar sağlamaktadır. Ancak, L. leucocephalańn bünyesinde bulunan mimosine isimli amino asit zaman zaman otlatılan hayvanlarda toksik etki yaparak çeşitli rahatsızlıklara sebep olmaktadır (Garcia ve ark. 1996). Bu bakımdan yüksek miktardaki karışım oranları ile hazırlanan silajların hayvanlara yedirilmeden önce mimosine içeriğinin tespit edilmesi gerekmektedir.

\section{TEŞEKKÜR}

Bu çalışma, Akdeniz Üniversitesi Bilimsel Araştırma Projeleri tarafından desteklenen 2012.01.0104.001 nolu projenin bir kısmıdır.

Duncan DB (1955) Multiple range and multiple F tests. Biometric $11: 1-42$.

Filya İ (2001) Silaj Fermantasyonu. Atatürk Üniversitesi Ziraat Fakültesi Dergisi 32 (1): 87-93.

Filya I (2004) Nutritive value and aerobic stability of whole crop maize silage harvested at four stages of maturity. Animal Feed Science and Technology 116: 141-150.

Filya I, Sucu E (2010) The effects of lactic acid bacteria on the fermentation, aerobic stability and nutritive value of maize silage. Grass and Forage Science 65: 446-455.

Garcia GW, Ferguson TU, Neckles FA, Archibald KAE (1996) The nutritive value and forage productivity of Leucaena leucocephala. Animal Feed Science Technology 60: 29-41.

Geren H (2001) Bornova koşullarında ikinci ürün olarak yetiştirilen farklı mısır çeşitlerinde ekim zamanlarının silaj özelliklerine etkisi. Ege Üniversitesi Ziraat Fakültesi Dergisi 38: 47-54.

Geren H, Kavut YT (2009) İkinci ürün koşullarında yetiştirilen bazı sorgum (Sorghum sp.) türlerinin mısır (Zea mays L.) ile verim ve silaj kalitesi yönünden karşılaştırılması üzerine bir araştırma. Ege Üniversitesi Ziraat Fakültesi Dergisi 46(1):9-16.

Johnson LM, Harrison JH (2001) Scientific aspects of silage making. proceedings.

http://ucanr.org/alf_symp/2001/01-151.pdf. Erişim tarihi: 18 Ağustos 2010

Koç F, Özdüven ML, Yurtman IY (1999) Tuz ve mikrobiyal katkı maddesi ilavesinin mısır-soya karışımı silajlarda kalite ve aerobik dayanıklılık üzerindeki etkileri. Hayvansal Üretim 39-40: 64-71.

McDonald P, Henderson AR, Heron SJE (1991) Microorganisms. In: McDonald, P., Henderson, A.R. and Heron, S.J.E. (eds) The Biochemistry of Silage pp. 81-151. UK: Abersytwyth. 
Meena DVN, Ariharan VN, Nagendra PP (2013) Nutritive Value and Potential Uses of Leucaena Leucocephala as Biofuel-A Mini Review. Research Journal of Pharmaceutical, Biological and Chemical Sciences 4 (1): 515-582.

Meeske RJ, Ashbell G, Weinberg ZG, Kipnis T (1993) Ensiling forage sorghum at two stages of maturity with the addition of lactic acid bacterial inoculants. Animal Feed Science and Technology 43: 165-175.

Nursoy H, Deniz S, Demirel M, Denek N (2003) Sür olum döneminde biçilen kimi mısır hasıllarına üre ve melas katkılarının silaj kalitesi ile sindirilebilir kuru madde verimine etkisi. Turkish Journal of Vetenary and Animal Science 27: 93-99.

Özdüven L, Koç F, Polat C, Coşkuntuna L, Başkavak S, Şamlı HE (2009) Bazı Mısır Çeşitlerinde Vejetasyon Döneminin Silolamada Fermantasyon Özellikleri ve Yem Değeri Üzerine Etkileri. Tekirdağ Ziraat Fakültesi Dergisi 6(2): 121-129.

Queiroz OCM, Arriola KG, Daniel JLP, Adesogan AT (2013) Effects of 8 chemical and bacterial additives on the quality of corn silage. Journal of Dairy Science 96: 5836-5843
Seale DR, Pahlow G, Spoelstra SF, Lindgren S, Dellaglio F, Lowe JF (1990) Methods for the Microbiological Analysis of Silage. Proceeding of the Eurobac Conference 12-16 August, Uppsala, Sweden, pp: 147-164.

Silva MSJ, Jobim CC, Poppi EC, Tres TT, Osmari MP (2015) Production Technology and Quality of Corn Silage for Feeding Dairy Cattle in Southern Brazil. Revista Brasileira de Zootecnia 44(9): 303-313.

Skerman PJ, Cameron DG, Riveros F (1988) Tropical Forage Legumes, $2^{\text {nd }}$ ed. 692 ss, FAO, Roma.

Titterton M, Maasdorp BV (1997) Nutritional improvement of maize silage for dairying: mixed crop silages from sole and intercropped legumes and a long season variety of maize, 2 . Ensilage. Animal Feed Science and Technology 69: 263-270.

Van Soest P J, Robertson J D, Lewis B A. 1991. Methods for dietary fibre, neutral detergent fibre and non-starch polysaccharides in relation to animal nutrition. Journal of Dairy Science 74: 3583. 3597.

Weinberg ZG, Ashbell G (2003) Engineering aspects of ensiling. Biochemical Engineering Journal 13: 181-188. 